Wonhee Cho*

\title{
From Military Leaders to Administrative Experts: The Biography of the "Treacherous Minister" Temüder and his Ancestors
}

https://doi.org/10.1515/asia-2017-0006

\begin{abstract}
Temüder (d. 1322) was an influential Mongol official of the Yuan dynasty in the early fourteenth century. The compilers of the Yuanshi listed him as one of the six "treacherous ministers," and it is easy to simply dismiss him accordingly. However, a closer examination of the life of Temüder himself and his ancestors reveals how the Mongol elites adapted and changed throughout time, and specifically how the earlier generation of military leaders transformed into administrative experts in civil administration and fiscal reform. Based on his biography in the Yuanshi, supplemented with a few scattered records from literary collections of Han-Chinese contemporaries and Persianlanguage sources, this article reconstructs the lives of Temüder, his ancestors, and his sons. In addition to balancing Temüder's overwhelmingly negative image, this article ultimately shows how the ruling outsiders - here, the Mongol elites exemplified by the case of Temüder - also gained new expertise to further consolidate their rule over China, and provides a more complex and nuanced perspective for understanding the mid- to late-Yuan period.
\end{abstract}

Keywords: Yuan dynasty, acculturation, administration, treacherous ministers, Temüder

\section{Introduction}

Temüder (d. 1322, Ch. Tiemudie’er 鐵木迭兒 or 帖木迭兒) was not only one of the most influential high-ranking officials during the reign of Ayurbarwarda (Renzong, r. 1311-1320) and Shidebala (Yingzong, r. 1320-1323), but also one of the six individuals included in the "Biography of Treacherous Ministers jianchen zhuan 姦臣傳)” of the Yuanshi. What is less well-known is that he was a fourth-generation descendant of a Mongol general who fought together with Chinggis Khan and a strong advocate of fiscal reform and administrative

*Corresponding author: Wonhee Cho, Jangseogak Archives, Academy of Korean Studies, 323 Haogae-ro, Bundang-gu, Seongnam-si, Gyeonggi-do, 13455, Republic of Korea.

E-mail: wonheecho@gmail.com 
centralization. In spite of his accomplishments, labeled as a "treacherous minister," he has been overshadowed by the negative images and accordingly almost totally neglected in scholarly literature. However, the change in family status that occurred from Temüder's ancestors to Temüder himself, who served as one of the most influential officials of the early fourteenth century, exemplifies changes among the Mongol ruling elites, specifically in how they adapted and expanded their expertise throughout the thirteenth century, and continued to do so as they governed the conquered lands in the fourteenth century.

This article expands the scope of analysis beyond the "treacherous minister" himself and includes an analysis of the underappreciated details of his ancestors. It, therefore, focuses on how Temüder, a descendant of an illustrious military general, became one of the most powerful administrators of the mid-Yuan period. Temüder's administrative career provides a more nuanced understanding of the transformations of the Mongol elites after serving the government for four generations, an often-neglected perspective on the Mongols lost in both the broad characterization of the Mongols and detailed individual studies.

The main sources for reconstructing the life of Temüder and his ancestors consist of his biography in the Yuanshi, literary works that cover the lives of officials who interacted with Temüder, and scattered references to Temüder himself in the legal sources. Imperial eulogies that Emperor Ayurbarwarda commissioned and Cheng Jufu 程鉅夫 eventually wrote in 1312, ${ }^{1}$ together with a few scattered accounts in Persian sources, provide valuable original information especially about his ancestors. As he was labeled a "treacherous minister," the remaining records of Temüder are hostile and critical, and, to some degree, the sources provide grounds for such infamy. However, the overall image arising from mining these multiple sources is more balanced and provides a window into a crucial aspect of Mongol rule in China. Moreover, this analysis enables us to think beyond the broad generalization of the Mongols - be it the long negative perception of Mongols as destructive warriors or the newer images of Mongols as facilitators of cross-cultural exchange - and emphasizes the change over time, as signified in the family transformation from Temüder's ancestors to Temüder himself.

1 Cheng Jufu, a well-known Confucian scholar official in the late 13th to early fourteenth century, passed away in 1318 without witnessing Temüder's fall and eventual disgrace. Therefore, his works convey a positive image of Temüder's ancestors that is barely visible in later sources. On the life and work of Cheng Jufu, see the introduction in the recently published punctuated edition of Cheng's works. Cheng 2009: 1-9. 


\section{Temüder's ancestors}

To understand the rise of Temüder and the transformation of his family, we must start from the lives of his ancestors. Most biographies in the Yuanshi provide some details on the ancestral background, the place of origin, and the early life of their individual subjects. Temüder's biography barely provides any of this background information; its opening lines only mention the name of his father.

Fortunately, Cheng Jufu's eulogies commemorating Temüder's ancestors enable us to glimpse something of Temüder's family background. His greatgrandfather was a Mongol named *Suqai (Ch. Suohai 唆海). The eulogy dedicated to *Suqai, written as a poem, mostly consists of colorful vocabulary but falls short on detail. Nevertheless, it reveals that Temüder's great-grandfather had served Chinggis Khan and praises him for assisting in the founding of the Empire. The poem also describes * Suqai as wearing armor and holding a daggeraxe, clearing showing that he participated in military operations. ${ }^{2}$

Temüder’s grandfather was Bürilgidei (Ch. Bulianjidai 不憐吉帶 or 不憐吉多), literally meaning "a complete spear." He truly lived up to this name. Bürilgidei first served Ögödei Qa'an (r. 1229-1241), participated in the expedition against the Qiqchaqs during the 1230s, and engaged in operations in China during the reign of Güyük (r. 1246-1248). During the interregnum after Güyük's death and the following succession crisis, ${ }^{3}$ Bürilgidei remained loyal to Möngke. Accordingly, Möngke allocated troops to Bürilgidei in order to defend a region between BeshBaligh and Qaraqorum. ${ }^{4}$ He was also in charge of defense against potential aggression from Yesü Möngke, Buri, and Khoja, all descendants of Ögödei or Chaghadai (1183-1244) who opposed Möngke's succession. ${ }^{5}$ After Möngke had consolidated his control over the Empire, Bürilgidei participated in the expedition to southwest China led by Qubilai. ${ }^{6}$ Just like his father, and as his name implies, Bürilgidei was a proven and experienced general. ${ }^{7}$

2 Cheng 2009: 32.

3 See Allsen 1987: 18-44.

4 Juvaynī 1997: 246, 1912-1937: 202. Almost the exact same phrase is repeated in Rashīd 1971: 241, 1994: 727. His defense of Besh-Baligh is repeated in Juvaynī 1997: 585, 587; Juvaynī 1912-1937: 53, 57. 5 Song 1976: 44.

6 Cheng 2009: 32; Song 1976: 50. The Bulianjidai 不憐吉歹 in the Chinese sources and the Bürilgidei in Persian sources most likely refer to the same person. See Juvaynī 1997: 247n9.

7 Note that in Chinese sources there is another noteworthy Bürilgidei (Bulianjidai 不憐吉帶, ? - ca. 1328), the grandson of the famous general Uriyangqadai (Ch. Wulianghetai 兀良和台, 1200-1271). This Bürilgidei was later appointed as the Prince of Henan 河南王. Admittedly, there is no definitive evidence that confirms or negates the possibility that the Bürilgidei active in the early fourteenth century here was the Prince of Henan, Bulianjidai, rather than the grandfather of Temüder. However, 
Bürilgidei had at least two sons, *Murchi (Ch. Mu’erhuochi 木兒火赤) and ${ }^{\star}$ Qoor Buqa (Ch. Hulu Buhua 忽魯不花, 1229-?). *Murchi accompanied Qubilai, and probably his father Bürilgidei, during the expedition to Yunnan 雲南 and Wuchang 武昌 in the 1250s. He remained loyal to Qubilai (r. 12601294) during the succession struggle with his younger brother Ariq Böke (d. 1264) in the early 1260s. During this period, he also helped Qubilai in suppressing the rebellion of Li Tan 李壇, a powerful Han-Chinese military warlord who had ambitions to become a more independent ruler. ${ }^{8}{ }^{\star}$ Murchi died in this battle but was still praised for his bravery and ability to lead troops at the front. ${ }^{9}$

${ }^{\star}$ Murchi's brother and Temüder's uncle ${ }^{\star}$ Qoor Buqa was an exception among the ancestors of Temüder, as he was the first to be involved in civil administration rather than serving purely as a military leader. In 1261 , ${ }^{\star}$ Qoor Buqa was appointed Junior Chief Councilor of the Secretariat (zhongshu zuochengxiang 中書左丞相), ${ }^{10}$ one of the highest-ranking positions in the Secretariat, and the following year he also served as Head of Judges (du duanshiguan 都斷事官) of the Central Secretariat. ${ }^{11}$ Accordingly, the contemporary sources call him the "head of the Central Secretariat,"12 and he was praised for his contribution to the establishment of the Yuan government. ${ }^{13}$

In sum, we can see that most of Temüder's ancestors established themselves on the battlefield, participating in various expeditions from the time of Chinggis

other sources strongly support the possibility that they were two different individuals. For example, in contrast to the imperial eulogy commemorating Temüder's grandfather Bürilgidei that mentions his accomplishments in the 1250s, in the imperial eulogy commemorating the Bürilgidei, the Prince of Henan (also written by Cheng Jufu) does not mention any military accomplishment and only praises his commitment to administration (Cheng 2009: 51). Moreover, records of military activity are also missing from Tao Zongyi's work in which Tao discusses his own interaction with the Prince of Henan, Bürilgidei (Tao 1959: 158). Finally, the father of the Prince of Henan Bürilgidei, Aju 阿术, was born in 1234 (See Song 1976: 3124 which states that he died at the age of 54 sui 歲 in 1286), and that would mean that even if Aju had become a father early, it would be hard to imagine a young Mongol in his teenage years being assigned to the important military positions occupied by Temüder's grandfather.

8 On the rebellion of Li Tan, see Chan 1993.

9 Cheng 2009: 33. *Morqochi's eulogy says he participated and eventually died "suppressing the rebels in Jinan 濟南," the place of Li Tan's rebellion.

10 Wang 1985: 374. Wang Yun clearly adds the annotation that ${ }^{\star}$ Qulu Buqa was the second son of Bürilgidei and that he was 31 sui at that time.

11 Song 1976: 45.

12 Chen et al. 2011: 1104. In theory, the Senior Chief Councilor of the Secretariat (zhongshu youchengxiang 中書右丞相) would outrank ${ }^{\star}$ Qulu Buqa's position as Junior Chief Councilor, but in this period, the seemingly systematic Chinese titles do not necessarily reflect reality.

13 Cheng 2009: 33. 
Khan to Qubilai. They were living examples of the Mongol warriors who built the Empire on horseback. By the third generation, however, the members of this once militant family had already been expanding their expertise into civil administration, as seen in the service of ${ }^{\star}$ Qoor Buqa.

\section{Accumulating experience}

Temüder's rise to power did not occur suddenly. Three factors - his family background, the breadth of his experience in the central and local government, and his connections to the imperial household - contributed to his success.

Temüder started his career during Qubilai's reign, but his specific role is unclear. Considering that he was a fourth-generation descendant of an influential Mongol family with a long history of serving the Empire, Qubilai possibly appointed him as a member of the imperial guards, the keshig. Then, during Temür's reign (1294-1307), Temüder served as Associate Director of the Bureau for Imperial Household Provisions (tongzhi huizhengyuan shi 同知宣 徽院事) and subsequently as the Director of the Bureau for Communications Services (tongzhengyuan shi 通政院使). ${ }^{14}$

The significance of the first position deserves a closer explanation. The Associate Director of the Bureau for Imperial Household Provisions was the second-highest-ranking position in the Bureau, which oversaw food supplies and provision for the imperial household and members of the imperial bodyguard, as well as sacrificial objects for state rituals. The high rank of this office (congyi 從一, 1B), the second-highest following zhengyi 正一, 1A), and the ability of its holder to select his own officials without going through the Central Secretariat's approval processes attest to its importance. ${ }^{15}$ This Bureau was in fact the reincarnation of the keshig position known as ba'urchi (Mo. “cook," but also "steward" or "commissary"), whose holders maintained proximity to the emperor. The office often served as a springboard for illustrious careers, as seen in the rather well-known examples of the grand historian Rashīd al-Dīn (d. 1318) in Iran, the "cultural broker" Bolad (d. 1313), and the influential minister El Temür (d. 1333). ${ }^{16}$ Temüder's appointment to this position further supports the assumption that he started his career in the keshig. It

14 Song 1976: 4576.

15 Farquhar 1990: 73.

16 Allsen 2001: 127-128; Lee 2004: 190. 
was also probably in this period that he formed close connections with members of the imperial family, especially the Empress Dowager Targi (d. 1322), who remained his most powerful ally. ${ }^{17}$

After Temür's death and throughout the rule of Qaishan (Wuzong, r. 1307-1311) Temüder held several high-ranking positions in both central and local government. In 1307, he served as one of four Directors of the Bureau for Imperial Household Provisions ${ }^{18}$ and the Privy Councilor of Jiangxi Branch Secretariat (Jiangxi xingsheng pingzhang zhengshi 江行省平章 政事). ${ }^{19}$ Later, in 1308, he was the Senior Chief Councilor of the Central Secretariat $^{20}$ and then the Junior Vice Councilor of Yunnan Branch Secretariat (Yunnan xingsheng zuochengxiang 雲南行省左丞相). ${ }^{21}$ Temüder's experience in the local governments of Jiangxi and Yunnan must have provided valuable experience for the reforms he later proposed that addressed both central and local government, as we will see below.

Temüder seemingly did not enjoy his time in Yunnan, as his response to this appointment resulted in a rather radical measure. In 1310, two years after being sent to Yunnan, he left his position without permission and returned to the capital. Such insubordinate behavior prompted the Secretariat of State Affairs (shangshusheng 尚書省) ${ }^{22}$ to submit a memorial requesting an investigation, and the emperor approved this request. ${ }^{23}$ This is when the sources first reveal the influence of one of Temüder's most powerful allies - the Empress Dowager Targi. Due to her intervention, any charges against Temüder were dismissed, and although he had to return to Yunnan, he did so without punishment. ${ }^{24}$

\section{Reformer or dictator?}

In the first five years of Ayurbarwarda's reign, Temüder became one of the most powerful individuals in the Yuan government. During the transition between

17 On Targi see Song 1976: 2900; Zhao 2008: 74-75.

18 Song 1976: 4576.

19 Song 1976: 484.

20 Song 1976: 497.

21 Song 1976: 4576.

22 Initially established to deal with fiscal issues, the Secretariat of State Affairs' authority expanded in Qaishan's era as it replaced the Central Secretariat and overtook its responsibilities. Hsiao 1994: 510-511.

23 Song 1976: 529, 4576.

24 Song 1976: 4576. 
Qaishan and Ayurbarwarda in 1311, on Targi's initiative, Temüder returned to the capital from Yunnan and once again became the Secretariat's Senior Chief Councilor. ${ }^{25}$ The newly crowned Emperor Ayurbarwarda also supported Temüder. In the edict announcing his accession, the emperor clearly stated how the wrongdoings of the Qaishan era would be fixed under the new leadership of the Central Secretariat, led by Councilor Temüder himself and two Privy Councilors, Öljei (Ch. Wanze 完澤) ${ }^{26}$ and Li Meng 李孟. ${ }^{27}$ As Ayurbarwarda left for Shangdu after his enthronement, he ordered Temüder to oversee Dadu, demonstrating his confidence in Temüder. Later, in 1312, the emperor also granted Temüder's ancestors various honorary titles and commissioned the composition of the eulogies we examined above. ${ }^{28}$

During this first service as the Senior Chief Councilor of the Central Secretariat, Temüder initiated a series of reforms centered on administrative discipline, enhancing the security of the emperor, and consolidating the power of the central government. In 1312, Temüder submitted a memorial emphasizing how he strived to fix problems within the government. He also criticized the incompetence of a significant number of officials who had relied on "luck" to gain their positions, and requested their dismissal. In another memorial, he insisted on heightened security on the emperor's travel from Dadu to Shangdu. ${ }^{29}$ Two months later, he insisted that the darugachis of appanages granted to the imperial princes should be appointed by the central government rather than the princes themselves. ${ }^{30}$

One month later, Ayurbarwarda issued an edict ordering that 1,073 jing 頃 of land from Guide 歸德 and Baozhou 毫州 (modern-day Henan), previously granted to a "Bulianjidai" by Emperor Möngke, should be returned to his "sons and grandsons," 31 probably including Temüder. Although this suggests that the emperor was pleased with Temüder's suggestions, soon afterwards, in

25 Song 1976: 537, 4576; Fang 2001: 688-689.

26 For this Öljei, a Uyghur, see Song 1976: 3227-3228. He should not be confused with the more famous Öljei of the Tubegen, who died in 1303. See Song 1976: 3173-74.

$27 \mathrm{Li}$ Meng is mostly famous for his advocacy to restore the civil service examination. Song 1976: 4084-4090. The edict announcing this change is found in Song 1976: 540 (omitting Öljei); Chen et al. 2011: 21-22; Yao 2011: 9.

28 Song 1976: 4577.

29 Song 1976: 2537.

30 Chen et al. 2011: 296-297; Meng 2006: 123-124; Endicott 1989: 99-101.

31 Song 1976: 551. Here I am assuming this Bulianjidai is referring to Temüder's grandfather, not the other Prince of Henan, Bulianjidai. See note 7. 
early 1313, Temüder voluntarily left the government due to health reasons. ${ }^{32}$ One year later, in 1314, Temüder returned to the central government on the recommendation of Councilor Hasan (Ch. Hasan 哈散), receiving from the emperor the honorific title of the Most Honored (kaifu yitong sansi 開府儀 同三司), in addition to the title of Chief Compiler of the Dynastic History (jianxiu guoshi 監修國史) $)^{33}$ and Overseer of Important Military and Political Affairs (lu junguo zhongshi 錄軍國重事). Later in the same year, he returned to the position of Senior Chief Councilor to the Central Secretariat, ${ }^{34}$ while Hasan remained as the Secretariat's Junior Chief Councilor.

Upon his return in 1314, Temüder submitted a long list of proposals for reform. The items in the proposal can be classified into the following four categories $^{35}$ :

1) A systemization of governmental procedures based on the Central Secretariat, targeting especially unofficial personnel or palace attendants (neishi 內侍) who did not follow standard procedures.

2) Increased control over non-governmental trading activities, resulting in the updated regulations on maritime trade of $1314 .^{36}$ These targeted unofficial trading activities that Temüder argued enabled merchants to evade taxation, increase prices on imported goods, and profit through usury.

3) A governmental advance purchase of salt certificates and iron smelting equipment in Shandong 山東 and Hejian 河間 (modern-day Hebei province) to deal with the expected increases in expenses.

4) A comprehensive land survey in Jiangzhe 江浙, Jiangdong 江東, and Jianxi 江西, especially targeting the lands of imperial princes, sons-in-laws, and institutions dedicated to religion or education. ${ }^{37}$

32 See Song 1976: 2818, 4580; on the unlikely possibility of Temüder being dismissed, see Yu 2007: 1063.

33 The exact role of the Chief Compiler of the Dynasty History is unclear and potentially misleading, since there was no dedicated National History Academy in the Yuan, and the compilation of the history of the previous dynasties was mostly stagnant during Temüder's time. See Chan 1981: 67-68; Farquhar 127-128.

34 Song 1976: 566.

35 Song 1976: 4577-4578.

36 Fang 2001: 533-538.

37 Temüder's focus on seeking new sources of taxation served as an alternative to the other possibilities, such as raising taxes, introducing new forms of taxation, or expanding the issue of paper bills, all of which he rejected. 
Because of the breadth and sophistication of these reforms, some scholars have questioned whether Temüder deserved credit for all of them. ${ }^{38}$ Yet, as we had seen above, Temüder himself had first-hand experience in Jiangxi, one of the areas proposed for the land survey, and his wide-ranging administrative experience would have helped him understand the problems addressed in these proposals. Even if these reforms do not all bear the direct hand of Temüder himself, there is no doubt that he was aware of these issues, and willing to propose them in his name.

Not all of Temüder's reforms can be considered successful. His fiscal reforms centered on the land surveys backfired as they caused a revolt led by a "local bandit” named Cai Wujiu 蔡五九, who temporarily occupied Tingzhou 汀州 (modern-day Jiangzhe) and declared himself king. The Yuan government quickly suppressed the rebellion, pacifying the region within two months, ${ }^{39}$ but not only did the emperor abandon the land survey, he also granted numerous land tax breaks to various regions in the following years. Moreover, this failure left Temüder with a bad reputation, as officials continuously criticized this attempt, even after his death. ${ }^{40}$ The results of his other reform proposals, however, are not specified in the sources.

Despite the failure of some of his proposals, Temüder's position within the government was not necessarily threatened, as he remained Senior Chief Councilor of the Central Secretariat. There were, however, some administrative changes. One year after these proposals, in 1315, Temüder requested that the tasks of the Central Secretariat be divided among its various officials, delegating various responsibilities to different individuals. The officials assigned to these tasks were an interesting mix of both Temüder's supporters and his later enemies. $^{41}$

Neither the redistribution of responsibilities nor his own partial failure brought Temüder down. In fact, later in 1315, in addition to all his previous positions, Temüder was appointed to oversee the affairs of the Bureau of Tibetan and Buddhist Affairs (xuanzhengyuan 宣政院), an office that not only dealt with Buddhists but also supervised some of the Tibetan territories. Three months later, he was granted the honorific title of Grand Preceptor (taishi 太師) on the order of the Empress Dowager Targi, ${ }^{42}$ and in the following month became the

38 Hsiao 1994: 522-523.

39 Song 1976: 570-571.

40 Meng 2006: 117-121.

41 Song 1976: 4578.

42 Song 1976: 4073. 
de facto head of the High Court for Mongols (dazongzhengfu 大宗正府). ${ }^{43}$ This was the height of Temüder's career, as he simultaneously headed multiple high-level governmental agencies. However, what Temüder exactly accomplished with all this authority from 1315 to 1317 is unclear in the sources.

A round of new policies following a change in regime is by no means a new thing. The reforms initiated and conducted by Temüder remain significant, however, even compared to other reforms in the Yuan dynasty. First and foremost, Temüder centered his reforms on fixing problems from the previous era, the reign of Qaishan. Qaishan's rule was plagued with an unorganized rapid growth of the bureaucracy - most visible through the controversial expansion of the Department of State Affairs (shangshusheng 尚書省) - and suffered from financial problems including the inflation caused by the introduction of new bills and coins. ${ }^{44}$ It is no surprise that Temüder's policies focused on strengthening and reestablishing the authority and functionality of the Central Secretariat and also seeking new sources of governmental revenues while rejecting suggestions to raise taxes or increase the circulation of paper bills. Second, it was Temüder himself, a third-generation Mongol, who single-handedly spearheaded these reforms, not a hired non-Mongol - such as Ahmad (? - 1282) or Sangha (? - 1291) during the reign of Qubilai ${ }^{45}$ or the Uyghur Toghto under Qaishan. Temüder's sole control over, and centrality to, the reforms arguably caused contemporary and later individuals to regard him as a dictator, but the significance of his reforms or the fact that a Mongol himself led the reform deserves more attention.

\section{Fall, return, and the end of an era}

In the last seven years of his life (1315-1322), Temüder experienced both ups and downs. He lost power in 1317, but returned to prominence after Emperor Ayurbarwarda's demise in 1320, initiating another round of reforms. He gradually lost power again, however, ending his controversial life without much impact. His sons never reclaimed the honor and authority of their father.

The first attack against Temüder occurred in 1315. Zhang Gui 張桂, a military commander active since Qubilai's reign who had climbed all the way to the

43 Song 1976: 4578.

44 Hsiao, 507-512.

45 For Ahmad and Sangha, see Franke 1993a; Franke 1993b. 
posts of Assistant Director of the Bureau of Military Affairs (shumifushi 樞密副使) and Privy Councilor, was the first to openly criticize Temüder, claiming that he was unqualified for the position of the Grand Preceptor. In response, the Empress Dowager Targi issued her own edict summoning Zhang Gui and had him beaten, forcing him to leave the capital due to injuries from this punishment. ${ }^{46}$ Zhang Gui alone could not take Temüder down.

The second and more critical attack occurred two years later, in 1317. Vice Censor-in-Chief (yushi zhongcheng 御史中丞) Yang Dorji, Senior Vice Councilor of the Secretariat Xiao Baiju, and Protector of the Capital (liushou 留守) He Sheng 賀勝 ${ }^{47}$ led the accusations against Temüder. The long list of Temüder's wrongdoings included receiving bribes from various people, confiscating lands illegally, harassing officials for his own benefit, and appointing his allegedly incompetent sons to high-ranking positions. More than forty officials from both the central and local government jointly submitted this document. Ayurbarwarda was enraged and ordered Temüder's arrest. Fleeing and hiding at a place near the residence of the Empress Dowager, Temüder avoided further punishment, thanks to the Empress Dowager's protection, but still lost all his official positions. ${ }^{48}$

Within two years of his dismissal, Temüder returned to power in 1319, being appointed Grand Preceptor for the Heir Apparent (taizi taishi 太子太師), serving the future Emperor Shidebala. Yet again, a group of officials within the Censorate, this time led by Vice Censor-in-Chief Zhao Shiyan 趙世延, immediately attempted to impeach him. Once more, due to the Empress Dowager's support, Temüder retained this single position, but he was unable to recover any of his former appointments. The efforts of the censorial officials to block his influence in the government were thus partially successful. ${ }^{49}$

Temüder reclaimed power during the peaceful transition from Emperor Ayurbarwarda to Shidebala in 1320. There were, however, significant

46 Song 1976: 4073. Hsiao's claim that Zhang Gui was beaten in 1319 seems to be an error. Hsiao 1994: 525.

47 He Sheng, who adopted the Mongol name Bayan 伯顏, started his career in the keshig, and later inherited his father's position of Protector of Shangdu (shangdu liushou 上都留守). Song 1976: 4149-4151.

48 Song 1976: 579, 4153-4154, 4578.

49 I have not been able to find the sources supporting Hsiao's claims that Temüder controlled the government during the last six months of Ayurbarwarda's reign (Hsiao 1994: 525, n.157). Temüder's name does not appear in the Basic Annals, nor in any of the collections of legal documents from this period, in contrast to the earlier period (1314 to 1317), in which he is more actively recorded. 
challenges and tensions among the higher-ranking officials. First, when Ayurbarwarda passed away, the Empress Dowager Targi again appointed Temüder as Senior Chief Councilor to the Secretariat. Then Temüder launched a series of attacks against his former enemies. Within 1320, Temüder certainly removed a significant number of his political opponents. ${ }^{50}$ The purge that took place in the transition period was by no means limited to Temüder's enemies, however, as the emperor also executed some of Temüder's former allies, who were accused of treason. ${ }^{51}$ The first was Hasan, the former Junior Chief Councilor of the Secretariat who had recommended Temüder's return to the Central Secretariat in 1314. The second was the Head of the Dowager Empress's Bureau (huizhengyuan 徽政院), Shiremün (Ch. shiliemen 失烈門), who had previously cooperated with Temüder in purging Xiao Baiju and Yang Dorji.

After everything had settled down, Temüder held onto his high rank. Again multiple honorary titles were bestowed on him, such as the Most Honored, Supreme Pillar of the State (shangzhuguo 上柱國), Grand Preceptor, ${ }^{52}$ and later the title of Grand Marshal (taiwei 太尉). ${ }^{53}$ The emperor even issued an edict to build a stele to commemorate Temüder's ancestors. ${ }^{54}$ Later, in 1321, he was once again appointed to oversee the Bureau of Tibetan and Buddhist Affairs. ${ }^{55}$

With these positions in hand, Temüder again introduced a series of reforms that were broadly consistent with those he had proposed during Ayurbarwarda's reign. The first fiscal reform he initiated in 1320, immediately after returning to office, focused on examining the granary reserves and implementing stricter control on tax collection. ${ }^{56} \mathrm{He}$ also initiated administrative reforms to strengthen his control over governmental affairs. ${ }^{57}$ There is no sign, however, of policies as drastic or significant as those introduced during Ayurbarwarda's reign, perhaps due to Shidebala's shorter rule.

The end of Temüder's life was rather uneventful. With most of his enemies gone, nobody attempted open criticism. He had also established close

50 Song 1976: 4580-4581. Yang Dorji, Xiao Baiju, He Sheng and Zhao Shiyan were either dismissed or executed.

51 Song 1976: 602; Chen et al. 2011: 112-113.

52 Song 1976: 600.

53 Song 1976: 603.

54 Song 1976: 611.

55 Song 1976: 612.

56 Song 1976: 4580; Chen et al. 2011: 2230-2231.

57 Song 1976: 601. 
connections with the emperor himself when Shidebala was heir apparent, and Targi, still powerful, now Grand Empress Dowager, remained his ally. However, Temüder's biography says that Emperor Shidebala gradually came to recognize Temüder's wrongdoing and shifted his trust toward the newly appointed Junior Chief Councilor of the Central Secretariat, Baiju (1298-1323), a descendant of Chinggis Khan's famous general, Muqali. ${ }^{58}$ Baiju slowly but surely distanced Temüder from the emperor. Unlike many of the Yuanshi's so-called treacherous ministers, Temüder died of natural causes in 1322, ${ }^{59}$ and Empress Targi also passed away in 1322. Posthumous disgrace followed soon after. In 1323, on the basis of detailed reports of his wrongdoing submitted by the officials of the Censorate, the emperor retracted Temüder's official positions and ordered the destruction of the stele built to commemorate his ancestors. ${ }^{60}$

Temüder had five sons, all of whom met different ends. One of them, named *Bars-jisu (Ch. Balajisi 八思吉思), was appointed Director of the Bureau of Tibetan and Buddhist Affairs (xuanzhengyuan shi 宣政院使), but was later executed for receiving bribes in $1322 .{ }^{61}$ In 1323, another son, *Baldan (Ch. Bandan 班丹), who was the Overseer of the Bureau of Military Affairs (zhi shumiyuan shi 知樞密院事) was beaten and dismissed for the same reason, and never returned to the government. ${ }^{62}$ These persecutions against his brothers must have made another son, a Secretarial Censor (zhishu shiyushi 治書侍御史) named *Sonom (Ch. Suonan 鎖南), anxious. It is thus not surprising that he ended up joining the coup led by ${ }^{\star}$ Tegshi (Ch. Tieshi 鐵失) in murdering the Emperor Shidebala at Nanpo 南坡 (located thirty li south of Shangdu) in 1323, or at least was easily targeted for this accusation. ${ }^{63}$ However, * Sonom, like others accused of participating, was later executed by the newly crowned Yisün Temür (r. 1323-1328). Two other sons, ${ }^{\star}$ Soju (Ch. Suozhu 鎖住) and *Guwainnu (Ch. Guanyinnu 觀音奴), survived until 1330, when they faced an investigation for making amulets and conducting cursing rituals, which probably led to their execution. ${ }^{64}$

58 Song 1976: 3300-3306.

59 Song 1976: 624, 4581.

60 Song 1976: 630-631, 4581.

61 Song 1976: 626.

62 Song 1976: 632, 4581.

63 On this incident, see Hsiao 1994: 532-537.

64 All we know about these brothers' fate is that the government confiscated Suozhu's property and granted it as a permanent endowment to a Buddhist temple (Song 1976: 762). In the Yuan dynasty, those conducting black magic or cursing rituals were subject to execution. Chen et al. 2011: 1422. 


\section{Conclusion: the significance of the "treacherous minister"}

What does this examination of Temüder, his ancestors, and sons tell us about the Mongols in the early fourteenth century? To start with, Temüder's life highlights the transformation and adaptation of Mongol elites. Temüder's ancestors all established themselves as military leaders from the birth of the Mongol Empire onward. However, the lives of Temüder's uncle *Qulu Buqa and Temüder himself demonstrate how the ruling Mongols expanded their expertise into civil administration. Moreover, Temüder did not acquire his administrative skills from nowhere - before his prominence in the 1310s and 1320s, he had accumulated experience in various positions in the central and local government, experience that enabled him to initiate reforms that his ancestors could not have imagined.

Admittedly, Temüder himself was by no means the only third- or fourthgeneration Mongol who served as an administrative expert in the 14th-century Mongol rule over China. Other officials of similar heritage, such as Baiju, replaced Temüder in the final years of Ayurbarwarda's reign. However, in the process of emphasizing the diversity of the Mongols who truly were praiseworthy for recruiting individuals from various backgrounds to administer the empire, we easily neglect the transformation of the Mongol elites themselves. Broadly speaking, our understanding of Mongols has changed from seeing them as merely exploitative nomads to people more versed in hiring those capable of sophisticated imperial administration. Temüder, among others, stands as an example of the Mongols themselves being capable administrators. ${ }^{65}$

Nevertheless, why is Temüder depicted in such negative terms, both by his contemporaries and in later scholarship? Most importantly, Temüder's negative image fits into the dichotomy of the Han versus non-Han narrative, a simplistic but problematic approach that has existed since the fourteenth century and was reinforced later. The idea that Temüder represented the nomadic steppe culture, in contrast to the Han-Chinese culture represented by Li Meng (famous for advocating the restoration of the civil service exam) has a rather long history. The Yuanshi biography of Li Meng reads, “Concerning the Huangqing 皇慶 (1312-1313) and

65 On this changing view of the Mongols see Morgan 2007: 193-196. Detailed examples of this view include Kim's analysis of the dominance of Mongols among the list of the amirs (including administrative personnel) of Qubilai (Kim 2014-2015), and his emphasis on "Mongol imperial institutions" as tools of administration that existed all over the empire (Kim 2013). 
Yanyou 延祐 (1314-1320) eras, for every failure in politics, people always said it was due to Temüder; for every success, people attributed it to Li Meng."66 This Han versus non-Han perspective also over-emphasizes the factional dispute between the two as an uncontainable force that continued since the transition from the militaristic figure of Qaishan to the more civically aligned reigns of Ayurbarwarda and Shidebala, and continued to the coup at Nanpo, where a faction of Mongols, inaccurately connected to Temüder, murdered the Emperor Shidebala himself. ${ }^{67}$

This binary approach does not conform to what actually happened, however. From the very beginning of Ayurbarwarda's reign, Li Meng and Temüder collaborated in the reform process. In fact, some of Li Meng's own reform proposals, such as the emphasis on centralization and keeping in check nongovernmental bodies (including, but not limited to, imperial princes and religious groups), were also consistent with Temüder's policies. Although the two later had disagreements, and Temüder eventually advocated the ouster of Li Meng, this later conflict should not eclipse what they had previously accomplished together. ${ }^{68}$ Moreover, some of the officials who spearheaded Temüder's dismissal in the late 1310s - Yang Dorji, Xiao Baizhu, and Zhao Shiyan - were of Tangut, Kitan, and Onggüt descent respectively, indicating that the factional conflict was not simply between Han and non-Han. Finally, the connection between the officials who led the Nanpo coup and Temüder is, at best, questionable. Temüder was both dead and posthumously disgraced before the coup occurred, and the four of his sons who did not take part in it were not affected and survived the aftermath of the coup.

Second, Temüder has an image as an unusual, unchecked, and all-powerful dictator. This image is also questionable. Temüder's rise to power, which was based on his family background, keshig training, and accumulated administrative experience, followed a common route for reaching high office and should not be considered anomalous. ${ }^{69}$ He did benefit from a close connection to the Empress Dowager Targi, and although the authority and influence that Mongol noblewomen held within the Mongol-Yuan Empire was obviously significant, ${ }^{70}$

66 Song 1976: 4090.

67 This approach was seemingly emphasized early on by Xiao Gongqin and adopted in Hsiao Ch'i-ch'ing's seminal work (Xiao 1983; Hsiao 1994).

68 For the details of Li Meng's proposals and his dismissal due to Temüder's opposition, see Song 1976: 4087-4090.

69 Dardess 1973: 17.

70 Rossabi 1979. 
this alone does not explain Temüder's rise to power. Moreover, Temüder's power was held in check. In 1317, he was dismissed for corruption, and even when he returned a year later his role was limited to tutoring the heir apparent. Later, during Shidebala's reign, the Junior Chief Councilor of the Central Secretariat, Baiju, became more influential as Temüder's authority in the court gradually weakened until his death in 1322.

In sum, the examination of Temüder's career sheds light on an underappreciated aspect of the Mongol elites in the Yuan dynasty - the transformation of the Mongols themselves. A descendant of military leaders who became an experienced civil servant and a determined fiscal and centralized reformer, Temüder might not have been a contemporary favorite, yet his story is an enlightening example of how the elite Mongols changed their roles, gaining new expertise to further advance their rule of China. It thus provides a more holistic and nuanced understanding of this period.

Acknowledgements: I would like to thank Prof. Michal Biran and the two anonymous reviewers for multiple important remarks and corrections, and Dr. Sim, Young Hwan (Academy of Korean Studies) for his help on reconstructing the Mongolian names.

Funding: The research leading to these results has received funding from the European Research Council under the European Union's Seventh Framework Programme (FP/2007-2013)/ERC Grant Agreement 312397.

\section{Bibliography}

Allsen, Thomas T. (1987): Mongol Imperialism: The Policies of the Grand Qan Möngke in China, Russia, and the Islamic Lands, 1251-1259. Berkeley: University of California Press.

Allsen, Thomas T. (2001): Culture and Conquest in Mongol Eurasia. Cambridge, MA: Cambridge University Press.

Chan, Hok-Lam (1981): "Chinese Official Historiography at the Yuan Court: The Composition of the Liao, Chin, and Sung Histories”. In: China Under Mongol Rule. Edited by John D. Langlois. Princeton: Princeton University Press.

Chan, Hok-Lam (1993): “Li T'an”. In: In the Service of the Khan: Eminent Personalities of the Early Mongol-Yüan Period (1200-1300). Edited by Igor de Rachewiltz, Hok-lam Chan, Ch'i-ch'ing Hsiao and Peter W. Geier. Wiesbaden: Harrassowitz, 387-406.

Chen, Gaohua 陳高華 et. al. (ed.) (2011): Yuandianzhang 元典章: Dayuan shengzheng guochao dianzhang 大元聖政國朝典章 (Institutions of the Yuan Dynasty: Compendium of Statutes and Substatutes of the Sagely Administration of the Great Yuan Dynasty). Tianjin: Tianjin guji chubanshe. 
Cheng, Jufu 程钜夫 (2009): Cheng Jufu ji 程鉅夫集 (Collected Works of Cheng Jufu). Changchun: Jinlin weshi chubanshe.

Dardess, John W (1973): Conquerors and Confucians: Aspects of Political Change in Late Yüan China. New York: Columbia University Press.

Endicott, Elizabeth (1989): Mongolian Rule in China: Local Administration in the Yuan Dynasty. Cambridge: Harvard University Press.

Fang, Linggui 方齡貴 (ed.) (2001): Tongzhi tiaoge jiaozhu 通制條格校注 (Comprehensive Regulations and Statues of the Yuan: Collated and Annotated). Beijing: Zhonghua Shuju.

Farquhar, David (1990): The Government of China under Mongolian Rule: A Reference Guide. Stuttgart: Steiner.

Franke, Herbert (1993a): “Ahmad”. In: In the Service of the Khan: Eminent Personalities of the Early Mongol-Yüan Period (1200-1300). Edited by Igor de Rachewiltz, Hok-lam Chan, Ch'i'-ch'ing Hsiao and Peter W. Geier. Wiesbaden: Harrassowitz, 539-557.

Franke, Herbert (1993b): "Sangha". In: In the Service of the Khan: Eminent Personalities of the Early Mongol-Yüan Period (1200-1300). Edited by Igor de Rachewiltz, Hok-lam Chan, Chi '-ch'ing Hsiao and Peter W. Geier. Wiesbaden: Harrassowitz, 558-583.

Hsiao, Ch'i-ch'ing (1994): “Mid-Yüan Politics”. In: The Cambridge History of China: Alien Regimes and Border States, 907-1368. Edited by Herbert Franke and Denis Twitchett. Cambridge: Cambridge University Press, 490-560.

Juvaynī, 'Alā' al-Dīn 'Ațā Malik (1912-1937): The Ta'rīkh-i-Jahán-gushá of 'Alá'u 'd-Din 'Ațá Malik-i-Juwaynī. Edited by Muḥammad Qazvīnī. Leiden: E. J. Brill.

Juvaynī, 'Alā' al-Dīn 'Ațā Malik (1997): Genghis Khan: The History of the World Conqueror. Translated by John Andrew Boyle. Seattle: University of Washington Press.

Kim, Hodong (2013): “Monggolchegugŭi segyejŏngbokkwa chibae - kŏshijŏng shiron 몽골제국의 세계정복과 지배: 거시적 시론 (The Birth of Mongol World Empire and Its Imperial Institutions: A Preliminary Essay)”. Yǒksahakpo 역사학보 217: 73-106.

Kim, Hodong (2014-2015): “Qubilai's Commanders (Amirs): A Mongol Perspective”. Archivum Eurasiae Medii Aevi 21: 147-160.

Lee, Yonggyu (2004): "Seeking Loyalty: The Inner Asian Tradition of Personal Guards and Its Influence in Persia and China." Unpublished Ph.D. Dissertation, Cambridge MA: Harvard University.

Meng, Fanqing 孟繁清 (2006): “Guanyu Tiemudie'er de jige wenti 關於鐵木迭兒的幾個問題 (A Few Questions Related to Temüder)”. Zhongguo shi yanjiu 中国史研究 2006 4: 117-130.

Morgan, David (2007): The Mongols. 2nd edition. Oxford: Blackwell Publishing.

Rashīd al-Dīn Ṭabīb (1971): The Successors of Genghis Khan. Translated by John Andrew Boyle. New York: Columbia University Press.

Rashīd al-Dīn Ṭabīb (1994): Jāmi‘ al-tavārīkh. Edited by Muḥammad Rawshan. Tehran: Nashr-i Alburz.

Rossabi, Morris (1979): "Khubilai Khan and the Women in His Family”. In: Studia SinoMongolica: Festschrift für Herbert Franke. Edited by Wolfgang Bauer. Wiesbaden: Franz Steiner, 153-180.

Song, Lian 宋濂 (1976): Yuanshi 元史. (The Official History of the Yuan Dynasty). Beijing: Zhonghua shuju.

Tao, Zongyi 陶宗儀 (1959): Nancun Chuo Geng Lu 南村輟耕錄. (Nancun's Notes while Resting from the Plough). Beijing: Zhonghua shuju.

Wang, Yun 王惲 (1985): Qiujian xiansheng da quanji 秋澗先生大全集 (Complete grand collected works of the Master Qiujian). Taibei: Xinwenfeng chuban gongsi. 
Xiao, Gongqin 蕭功秦 (1983): “Yingzong xinzheng yu ‘Nanpo zhi bian’ 英宗新政與南坡之變 (The New Policies of Yingzong and the 'Coup of Nanpo'”. Yuanshi Luncong 元史論叢 2: 145-156.

Yao, Sui 姚燧 (2011): Yao Sui ji 姚燧集 (YaoSui's Literary Collection). Edited by Cha Hongde 查洪德. Beijing: Renmin Wenxue chubanshe.

Yu, Ji 虞集 (2007): Yu Ji quanji 虞集全集 (Complete Collected Works of Yu Ji). Tianjin: Tianjin guji chubanshe.

Zhao, George Qingzhi (2008): Marriage as Political Strategy and Cultural Expression: Mongolian Royal Marriages from World Empire to Yuan Dynasty. New York: Peter Lang Publishing. 